\title{
Levels of C-reactive protein in serum samples from healthy children and adults in São Paulo, Brazil
}

M.A. Ribeiro

\author{
Correspondence \\ M.A. Ribeiro \\ Seção de Imunologia \\ Instituto Adolfo Lutz \\ Av. Dr. Arnaldo, 355, 110 andar \\ 01246-902 São Paulo, SP \\ Brasil \\ Fax: 55 (011) 853-3505
}

Publication supported by FAPESP.

Received October 24, 1996

Accepted July 15, 1997
Seção de Imunologia, Instituto Adolfo Lutz,

São Paulo, SP, Brasil

\begin{abstract}
C-reactive protein (CRP) was measured by ELISA in the sera of 165 healthy blood donors and 125 normal children 1 to 14 years old. The serum levels of blood donors ranged from 0.05 to $57.6 \mathrm{mg} / \mathrm{l}$ with median and mean values of $1.8 \mathrm{mg} / \mathrm{l}$ and $4.86 \mathrm{mg} / \mathrm{l}$, respectively. CRP levels ranged from 0.02 to $14.4 \mathrm{mg} / \mathrm{l}$ in the children's sera, the median being $0.45 \mathrm{mg} / \mathrm{l}$ and the mean $1.65 \mathrm{mg} / \mathrm{l}$. No individual lacking CRP was detected. The high CRP levels observed in the present study suggest that the population of the State of São Paulo may usually be exposed to subacute infections and/or inflammation without presenting clinical symptoms.
\end{abstract} Key words - C-reactive protein (CRP)

- Serum CRP

\section{Introduction}

In recent years, both clinical and basic research interests have focused on a more narrowly defined "acute phase response" which results in changes in the concentration of a number of plasma proteins as a consequence of the reorchestration of the pattern of plasma protein synthesis in hepatocytes. These proteins are referred to as the "acute phase proteins" (1).

C-reactive protein (CRP), the best-studied major acute phase protein in humans, was initially described in 1930 by Tillet and Francis Jr. (2) as the serum factor responsible for the precipitation of acute phase sera with the C-substance (C-polysaccharide, CPS) of pneumococcal cell walls. CRP was purified in 1941 by MacLeod and Avery (3), who developed a rabbit anti-CRP antibody, and crystallized by McCarty in 1947 (4). The complete amino acid sequence of human CRP was established by Oliveira et al. (5) and has no homology to immunoglobulins. CRP is a 120,000-140,000 molecular weight pentameric protein comprising five identical, noncovalently bound subunits arranged in cyclic symmetry on a single plane (6-8). Although CRP is structurally distinct from the immunoglobulins, it shares with them the ability to initiate several biological functions including precipitation (2), opsonization (9), capsular swelling (10) and agglutination (11). Two major biological activities of CRP have been well defined: first, it is able to bind several biological substrates that are distributed widely in nature (12). Second, it has significant activation capabilities, in particular to activate the complement system (13) and to bind to and modulate the function of phagocytic leukocytes $(14,15)$. These effects support the concept that this serum protein 
may have a potentially central role in host defense mechanisms. The major source of plasma CRP is the liver (16). Interleukin-6 plays a critical role in CRP induction (17).

Many early researchers were not able to detect "acute phase" protein in normal human sera using precipitation with CPS (2), capillary immunoprecipitation (18), complement fixation (19), latex agglutination (20) or agarose gel electrophoresis (21). Using double-diffusion in gel which has a sensitivity of approximately $500 \mu \mathrm{g} / \mathrm{l}$, Nilsson (22) found traces of CRP in sera from $50-75 \%$ of blood donors, and Saxstad et al. (23) were able to detect it in 17 of 98 apparently healthy infants. Later, Kindmark (24) reported the presence of CRP in sera from healthy blood donors using a radioelectro-immunoprecipitation assay which detected as little as $10 \mu \mathrm{g} /$ 1. Thus, earlier reports of the absence of this protein in sera from healthy individuals probably resulted from the limited sensitivity of the assay methods employed.

CRP levels can be quantitated precisely and rapidly by several techniques, including nephelometry (25), radioimmunoassay (26) and enzyme-immunosorbent assay (ELISA) $(27,28)$. As the use of quantitative methods to determine serum CRP levels has increased in recent years, a number of reports have described their use in helping solve specific diagnostic problems. Since quantitative CRP data are limited to relatively few specific disease states, the present study was undertaken to determine CRP concentration in the sera of healthy individuals in São Paulo.

\section{Material and Methods}

The CRP level of normal individuals was determined by assaying 125 blood samples from children (aged 1 to 14 years) from São João da Boa Vista, São Paulo, Brazil. Peripheral blood was collected just before the first vaccination with a Cuban serogroup BC vaccine performed in 1989. Sera from 165 clinically healthy blood donors were ob- tained from a local blood bank. None of the participants had clinical symptoms of disease. Personal consent was obtained. These serum samples were kindly provided by Dr. Amadeu Saez Alquezar, "Pró-Sangue" Foundation Blood Bank, and by Dr. Lucimar G. Milagres, Adolfo Lutz Institute, São Paulo Health Service. Sera were stored at $-20^{\circ} \mathrm{C}$ for 9 months prior to testing.

CRP concentrations were determined by ELISA with a sensitivity of $0.9 \mu \mathrm{g} \mathrm{CRP} / \mathrm{l}$ (28). Briefly, $100 \mu \mathrm{l}$ of serum samples serially diluted in $10 \mathrm{mM}$ phosphate buffered saline, $\mathrm{pH} 7.2$, containing $0.05 \%$ Tween-20 (PBS-T) and $1 \%$ bovine serum albumin, was added to polystyrene microtiter plate wells (Corning, New York) coated with capture antibody (rabbit anti-human CRP, Sigma Chemical Co., St. Louis, MO) and incubated for $2 \mathrm{~h}$ at $37^{\circ} \mathrm{C}$. The sample diluent was used as a negative control. After washing the plates four times with PBS-T, $100 \mu \mathrm{l}$ of peroxidase-conjugated rabbit IgG anti-human CRP (Sigma) was added to the wells at a 1:1000 dilution as determined by checkerboard titration. After an incubation period of $1 \mathrm{~h}$ at $37^{\circ} \mathrm{C}$ the plates were washed and developed with o-phenylenediamine in phosphate citrate buffer. Absorbance was measured with a spectrophotometer (Titertek Multiskan, MCC Flow Labs Inc., Finland) at $492 \mathrm{~nm}$. The serum titer was considered to be the reciprocal of the endpoint dilution corresponding to an absorbance value 2.1 times the mean absorbance of negative controls.

CRP concentrations obtained for children and adult groups were compared by the Mann-Whitney U-test and correlation coefficients were determined by the Spearman rank test as decribed by Zar (29). The level of significance was set at $\mathrm{P}<0.05$.

\section{Results}

A summary and the distribution of CRP levels in serum samples from healthy children and adults of São Paulo State, Brazil, 
are shown in Table 1 and Figure 1, respectively. The range of CRP concentration was very wide in each group. Most of these sera ( $80.8 \%$ of children and $60 \%$ of adults) had a CRP concentration below the detection limit of the radial immunodiffusion assay $(2 \mathrm{mg} / \mathrm{l})$ as indicated by the vertical line in Figure 1. CRP was detected in all sera analyzed. A weak negative correlation $(\mathrm{r}=-0.300 ; \mathrm{P}=$ 0.001) was observed between CRP concentration and age in the group consisting of children. The Mann-Whitney U-test revealed a significant difference $(\mathrm{P} \leq 0.00)$ in $\mathrm{CRP}$ concentration between children and adults.

\section{Discussion}

The determination of CRP in serum may be more generally useful than the erythrocyte sedimentation rate in current clinical practice, since this test permits the precise and direct quantitation of a single acute phase protein. The availability of this quantitation has underscored our relative lack of information about the clinical significance of different levels of CRP in man. Increased levels of this protein are detectable as early as $4 \mathrm{~h}$ following tissue injury; peaks are attained within 24 to $72 \mathrm{~h} \mathrm{(30)}$ and its concentration declines equally rapidly with recovery.

It is evident that a wide range of elevated serum CRP levels above those found in apparently healthy individuals may be observed in disease, and that their interpretation requires quantitative assessment. Increased levels of serum CRP have been found in virtually all diseases associated with active inflammation or tissue destruction, such as rheumatoid diseases, acute infectious processes, postmyocardial infarction or surgery, advanced and widespread malignancy, and chronic infections $(10,18,31)$. Thus, elevated CRP levels serve as a nonspecific indicator for the presence of one of these processes, rather than as an indicator of a specific pathology. CRP levels have been used clinically to gauge the presence and extent of
Table 1 - CRP levels in human sera as determined by ELISA.

The detection limit was $0.9 \mu \mathrm{g} C R P / 1$.

\begin{tabular}{lccccc}
\hline Sera & No. & $\begin{array}{c}\text { Range } \\
(\mathrm{mg} / \mathrm{l})\end{array}$ & $\begin{array}{c}\text { Average } \\
(\mathrm{mg} / \mathrm{l})\end{array}$ & $\begin{array}{c}\text { Median } \\
(\mathrm{mg} / \mathrm{l})\end{array}$ & $\begin{array}{r}\text { Standard } \\
\text { deviation }\end{array}$ \\
\hline Children (1-14 years) & 125 & $0.02-14.40$ & 1.65 & 0.45 & 2.69 \\
Adults & 165 & $0.05-57.60$ & 4.86 & 1.80 & 8.22
\end{tabular}

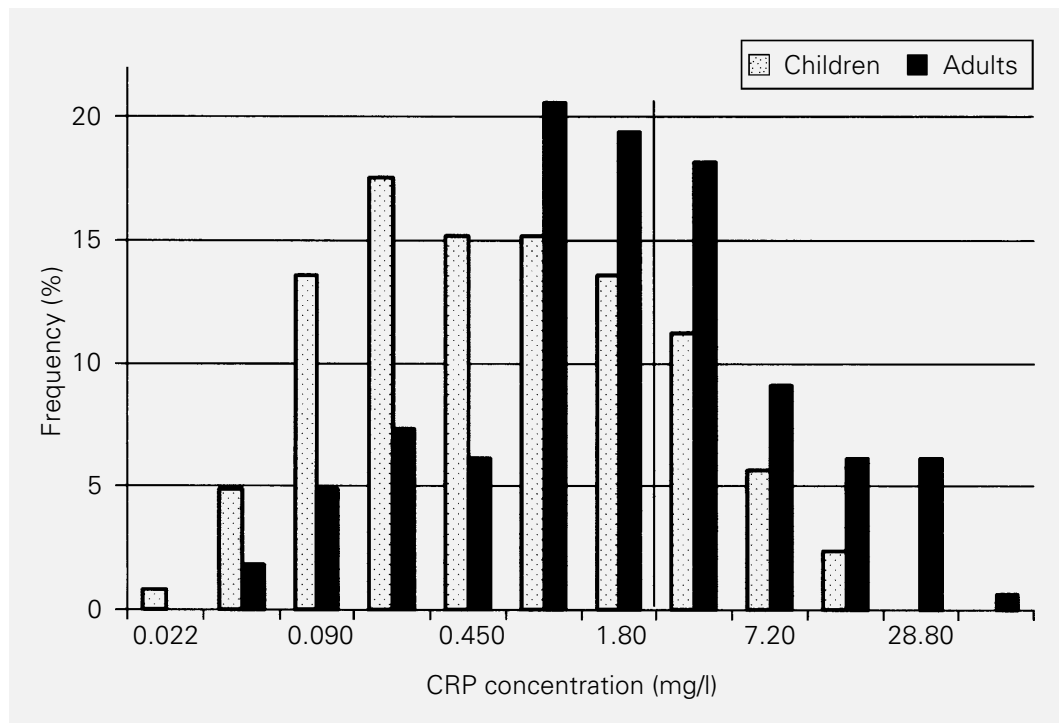

Figure 1 - Distribution of CRP levels in the sera of 125 normal children, aged 1 to 14 years, and 165 healthy blood donors determined by ELISA. Most of these sera $(80.8 \%$ of children and $60 \%$ of adults) had CRP concentrations below the detection limit of the radial immunodiffusion assay $(2 \mathrm{mg} / \mathrm{l})$, indicated by the vertical line.

inflammation, as well as to evaluate the effectiveness of anti-inflammatory therapy, mainly in rheumatoid diseases (18). The major finding in this area was the strong association between marked increases in serum CRP concentrations (over $100 \mathrm{mg} / \mathrm{l}$ ) and severe bacterial infections (32).

The normal CRP levels for adults have not been precisely defined, since relatively minor events during the course of daily living, such as the stubbing of one's toe or vigorous physical exercise, may induce minor elevations of CRP (1). According to Hokama and Nakamura (33), serum CRP levels appear to progressively increase with age. We did not find a progressive increase 
in CRP levels in sera of children aged 1 to 14 years, but the data obtained revealed that the CRP concentration in the sera from blood donors that represent selectively healthy adults was significantly higher than that observed in healthy schoolchildren. The dramatic difference in serum CRP levels found in the São Paulo State community as compared to those found in Sweden by Kindmark (24) reflects the need for a local pattern of normal values. This author found mean values of $0.17 \mathrm{mg} / \mathrm{l}$ and $0.47 \mathrm{mg} / \mathrm{l}$ for Swedish children and adults, respectively, while our results showed values of $1.65 \mathrm{mg} / \mathrm{l}$ for children and $4.86 \mathrm{mg} / \mathrm{l}$ for adults. His upper two sigma limits of the normal range were 2.2 $\mathrm{mg} / \mathrm{l}$ for children and $4.9 \mathrm{mg} / \mathrm{l}$ for adults whereas in our study these values were 7.03 and $21.30 \mathrm{mg} / \mathrm{l}$, respectively. Thus, while most of our serum samples had CRP levels of $3.6 \mathrm{mg} / \mathrm{l}$ or less $(78.18 \%$ adults and $92 \%$ children), levels up to $14.4 \mathrm{mg} / \mathrm{l}$ (minor or "nonsignificant" elevations) may be found occasionally in our apparently healthy individuals. The upper limit may also be calculated by excluding $2.5 \%$ of the samples (from 3 children and 4 adults) with the highest CRP concentrations. This would give an upper limit of about $7.2 \mathrm{mg} / \mathrm{l}$ for children and $28.8 \mathrm{mg} / \mathrm{l}$ for adults, values not far from the results obtained by the conventional method defined as the mean plus 2 x SD (29). Al- though an attempt was made to use sera exclusively from healthy individuals, it is possible that the higher CRP levels observed in our population were from individuals with a subacute infection and/or inflammation without presenting clinical symptoms. Even when rigorous standards were observed for vaccine application and the patient was in good clinical condition the possibility of small muscle injuries (for instance, application of intramuscular injections) or the presence of some intestinal parasites cannot be excluded. No information was obtained in this respect at the time of blood withdrawal. Kuvibidila et al. (34) reported that the range of CRP levels for non-pregnant female Zaireans were within published ranges for healthy adults. On the other hand, Samba et al. (35) reported that the CRP levels of healthy Congolese children were twice as high as those considered normal by Engler's criteria (36). In conclusion, each laboratory should establish its own reference range for each age group where possible, since differences occur depending on the population studied.

\section{Acknowledgment}

The author is grateful to Dr. Ione Irulegui for helpful suggestions for the preparation of the manuscript.

\section{References}

1. Ballou SP \& Kushner I (1992). C-reactive protein and the acute phase response. Advances in Internal Medicine, 37: 313336.

2. Tillet WS \& Francis Jr T (1930). Serological reactions in pneumonia with a nonprotein somatic fraction from pneumococcus. Journal of Experimental Medicine, 52: 561-571.

3. MacLeod CM \& Avery OT (1941). The occurrence during acute infections of a protein not normally present in the blood. II. Isolation and purification of the reactive protein. Journal of Experimental Medicine, 73: 183-190.
4. McCarty M (1947). The occurrence during acute infections of a protein not normally present in the blood. IV. Crystallization of C-reactive protein. Journal of Experimental Medicine, 85: 491-498.

5. Oliveira EB, Gotschlich EC \& Liu T-Y (1977). Primary structure of human C-reactive protein. Proceedings of the $\mathrm{Na}$ tional Academy of Sciences, USA, 74: 3148-3151.
6. Osmand AP, Friedenson B, Gewurz $\mathrm{H}$ Painter RH, Hofmann $T$ \& Shelton $E$ (1977). Characterization of C-reactive protein and the complement subcomponent $\mathrm{C} 1 \mathrm{t}$ as homologous proteins displaying cyclic pentameric symmetry (pentraxins). Proceedings of the National Academy of Sciences, USA, 74: 739-743.

7. Gotschlich EC \& Edelman GM (1965). Creactive protein: a molecule composed of subunits. Proceedings of the National Academy of Sciences, USA, 54: 558-566. 
8. Kushner I \& Somerville JE (1970). Estimation of the molecular size of C-reactive protein and $\mathrm{Cx}$-reactive protein in serum. Biochimica et Biophysica Acta, 207: 105114.

9. Ganrot PO \& Kindmark CO (1969). C-reactive protein - a phagocytosis-promoting factor. Scandinavian Journal of Clinical and Laboratory Investigation, 24: 215-219.

10. Hedlund P (1961). Clinical and experimental studies on C-reactive protein (acutephase protein). Acta Medica Scandinavica, 361 (Suppl): 1-71.

11. Patterson LT \& Higginbotham RD (1965). Mouse $\mathrm{C}$-reactive protein and endotoxininduced resistance. Journal of Bacteriology, 90: 1520-1524

12. Gotschlich EC, Liu T-Y \& Oliveira E (1982). Binding of $\mathrm{C}$-reactive protein to $\mathrm{C}$-carbohydrate and PC-substituted protein. Annals of the New York Academy of Sciences, 389: 163-171.

13. Kaplan MH \& Volanakis JE (1974). Interaction of C-reactive protein complexes with the complement system. I. Consumption of human complement associated with the reaction of C-reactive protein with pneumococcal $\mathrm{C}$-polysaccharide and with the choline phosphatides lecithin and sphingomyelin. Journal of Immunology, 112: 2135-2147.

14. Wood HF (1951). Effect of C-reactive protein on normal human leukocytes. Proceedings of the Society for Experimental Biology and Medicine, 76: 843-847.

15. Kindmark C-O (1971). Stimulating effect of $\mathrm{C}$-reactive protein on phagocytosis of various species of pathogenic bacteria. Clinical and Experimental Immunology, 8: 941-948.

16. Hurliman J, Thorbecke GJ \& Hochwald GM (1966). The liver as the site of Creactive protein formation. Journal of Experimental Medicine, 123: 365-378.

17. Castell JV, Gómez-Lechón MJ, David M, Fabra R, Trullenque R \& Heinrich PC (1990). Acute-phase response of human hepatocytes: regulation of acute-phase protein synthesis by interleukin-6. Hepatology, 12: 1179-1186.

18. Anderson HC \& McCarty M (1950). Determination of $\mathrm{C}$-reactive protein in the blood as a measure of the activity of the disease process in acute rheumatic fever. American Journal of Medicine, 8: 445-455.
19. Rapport MM \& Graf L (1956). Quantitative determination of C-reactive protein by complement fixation. Proceedings of the Society for Experimental Biology and Medicine, 93: 69-74.

20. Singer JM, Plotz CM, Pader E \& Elster SK (1957). The latex-fixation test. III. Agglutination test for $\mathrm{C}$-reactive protein and comparison with the capillary precipitin method. American Journal of Clinical Pathology, 28: 611-617.

21. Kindmark C-O (1969). Quantitative measurement of C-reactive protein in serum. Clinica Chimica Acta, 26: 95-98.

22. Nilsson L-Å (1968). C-reactive protein in apparently healthy individuals (blood donors) related to age. Acta Pathologica et Microbiologica Scandinavica, 73: 619-623.

23. Saxstad J, Nilsson L-Å \& Hanson L-A (1970). C-reactive protein in serum from infants as determined with immunodiffusion techniques. I. Healthy infants. Acta Paediatrica Scandinavica, 59: 25-27.

24. Kindmark C-O (1972). The concentration of $\mathrm{C}$-reactive protein in sera from healthy individuals. Scandinavian Journal of Clinical and Laboratory Investigation, 29: 407411.

25. Harmoinen $A$, Hällström $O$ \& Grönroos $P$ (1980). Rapid quantitative determination of C-reactive protein using laser-nephelometer. Scandinavian Journal of Clinical and Laboratory Investigation, 40: 293-295.

26. Claus DR, Osmand AP \& Gewurz H (1976). Radioimmunoassay of human Creactive protein and levels in normal sera. Journal of Laboratory and Clinical Medicine, 87: 120-128.

27. Hokama $Y$, Nobuhara WR, Munemasa K, Young PML \& Kimura LH (1984). Comparative sensitivity of an enzyme immunoassay (EIA) and other routine immunological methods for $\mathrm{C}$-reactive protein (CRP) analysis in plasma: ElA examination of cancer plasma. Proceedings of the American Association for Cancer Research, 25: 285 (Abstract 1129).

28. Ribeiro MA, Kimura RT, Irulegui I, Colletto GMDD, Ribeiro CE \& Farhat CK (1992). Cerebrospinal fluid levels of lysozyme, $\lg \mathrm{M}$ and $\mathrm{C}$-reactive protein in the identification of bacterial meningitis. Journal of Tropical Medicine and Hygiene, 95: 8794.
29. Zar JH (1984). Biostatistical Analysis. 2nd edn. Prentice Hall, Englewood Cliffs, NJ, 139-142.

30. Kushner I, Broder ML \& Karp D (1978). Control of the acute phase response. Serum C-reactive protein kinetics after acute myocardial infarction. Journal of Clinical Investigation, 61: 235-242.

31. Kroop IG \& Shackman NH (1954). Level of $\mathrm{C}$-reactive protein as a measure of acute myocardial infarction. Proceedings of the Society for Experimental Biology and Medicine, 86: 95-97.

32. Morley JJ \& Kushner I (1982). Serum Creactive protein levels in disease. Annals of the New York Academy of Sciences, 389: 406-418.

33. Hokama Y \& Nakamura RM (1987). Creactive protein: current status and future perspectives. Journal of Clinical Laboratory Analysis, 1: 15-27.

34. Kuvibidila S, Warrier RP, Yu L, Ode D \& Mbele $V$ (1994). Reference levels of acute phase reactant proteins in healthy Zairean women in reproductive age group. Journal of Tropical Medicine and Hygiene, 97: 239-243.

35. Samba C, Galan P, Luzeau R \& AmedeeManesme O (1990). Vitamin A deficiency in pre-school age Congolese children during malaria attacks. Part I. Utilization of the impression cytology with transfer in an equatorial country. International Journal of Vitamin and Nutrition Research, 60: 215-223.

36. Engler R (1984). Bases méthodologiques: protéines de la réaction inflammatoire. Notion du profil protéique. Pédiatrie, 39: 339-344. 